https://jurnal.ugm.ac.id/rubikon

\title{
AMERICAN JEWS AS A WHITE ETHNIC AND HOW THEY WERE PERCEIVED: A SOCIOLOGICAL APPROACH
}

\author{
Rizqy A.R. Ahmad \\ Universitas Muhammadiyah Kupang \\ e-mail: rizqy_ahmad@unmuhkupang.ac.id \\ Muh Arif Rokhman \\ Universitas Gadjah Mada \\ e-mail: arokhman@ugm.ac.id
}

\begin{abstract}
This study aims to determine the changes of American Jews social status from the 'other' to the white ethnic. Social Identity theory is used in order to breakdown how the American Jews were perceived. The classification as a white ethnic, while it has its benefits, does not automatically put the American Jews and the WASP in the exact same position. Rather, the American Jews managed to stay within their ethnic boundaries while enjoying the white privilege.
\end{abstract}

Keywords: American Jews; social identity; white ethnic; white privilege

DOI $\quad$ : https://doi.org/10.22146/rubikon.v7i1.62509

Available at https://jurnal.ugm.ac.id/rubikon/article/view/62509

This work is licensed under a Creative Commons Attribution-ShareAlike 4.0 International License

\section{INTRODUCTION}

Whiteness is a complicated matter. Since the $17^{\text {th }}$ century when the Puritan and black slaves came to America, WASP is the only race and ethnic which took the hold of white privilege. The establishment of white ethnic is a breakthrough in American society, because WASP was the sole owner of whiteness, despite the similarity of skin color with the Eastern European descent. Because of this, many ethnics and races desired to be recognized as white, or at least share the similar privilege with the WASP. The
Article information Received: 12 January, 2020 Revised: 26 January, 2020 Accepted: 9 February, 2020 acknowledgement of the American Jews as white, particularly white ethnic is also a life changing moment for the American Jews. Although the other white ethnics such as Italian and Irish also get acknowledged as white, but none of these ethnics have the same huge social change like Jews. With the help of education and the increase of financial power, the American Jews were able to lift their social status in a very different place than before, thus standing on the same road with the WASP. However, today whiteness has become the key which can lead to open many doors. Without it, 
the American Jews may not be where they are today.

Hence, the debates of the exact ethnicity and race of American Jews are still continued until today. Although the Census Bureau of the United States (Hixson, Hepler and Kim, 2010) has listed the Jews as white, it seems that this decision is provoking several sides' opinion; denying it half-heartedly or refusing it altogether to recognize the Jews as white. Living in America, to belong in the white shade of skin is truly a gift. The privilege that comes naturally for the white-skinned people are often frowned upon by many of the nonwhite citizen. There are a number of white people whom also admitting this discrimination, but many others are enjoying their skin privilege to the fullest, or even oblivious about this matter. As Eric Goldstein stated, "Jews were a racial conundrum, a group that could not clearly be pinned down according to the prevailing racial categories." And also that "in the minds of white Americans, Jews were clearly racial outsiders...demonstrating distinctive social patterns, clustering in urban neighborhoods...and largely marrying within their own group" (2005).

American Jews, as the second largest of Jews in the world with the population of approximately five million populations, actually don't have a very high number if it compared to the whole American population. In 2007, the number of Jewish is about $1,7 \%$ of the adults in America, with Christian as the largest number of American religious group with 78,5\% member of the adults in America (Miller, ed., 2008: 5). Since their first immigration to America, the Jews have taken part in many economy and politic activities. In the recent decades, the power of Jews' economy and politic is much stronger. Although their total population in America is $1,7 \%$, about half of the richest Americans were Jews (Berkman, 2009). And so the Jews that sit on the governmental positions. There are many strategic and influential positions in either economic or politic area that held by the Jews. This situation enable them to get help and support from higher authorities to fulfill the activity which in their favor.

However, this success doesn't save them from being discriminated in the society. Just like other non-white (or non-WASP in this matter) at the time, many American Jews children reported to be bullied at school, and they often considered as weak. In the society, their condition also not much better. At their first settlement in America, they lived in the ghettoes with bad environment. Although their skin can be considered as white, the WASP or European settlers does not consider Jewish as part of their group. The bullying was based on the anti-semit prejudices which often targeting people with the supposedly Middle Eastern physical appearance or descendant. The fact that they come from the Middle East (included before and after Jewish built Israel) makes them as 'other' in White society.

The white group itself can be found in race and ethnic categorization. The general meaning of race and ethnic is, while race usually regarded as biologically constructed categorization (which means can be categorized through physical appearance), ethnic often being seen as a sense of belonging, a social background and culture which bind a community. A definition provided by van den Berghe says that race is a human group that defines itself and/or is defined by other groups as different from other groups by virtue of innate and immutable physical characteristics 
(1967). Whereas an ethnic group is socially defined on the basis of cultural criteria, such as language, religion, or national origin (Lewins, 1978).

The white skinned people are the majority in America. They are majority in 49 out of 50 states, with Hawaii as the exception. White American itself consisted of $77.35 \%$ of total US population as of 2014 . The United States Census Bureau defines White people as those who "having origins in any of the original peoples of Europe, the Middle East-North Africa". The term 'Caucasian' also often used interchangeably with 'White', although the terms are not synonymous. Still according to U.S. Census Bureau 2010, the largest ancestries of American Whites are: German Americans (16.5\%), Irish Americans (11.9\%), English Americans (9.2\%), Italian Americans (5.5\%), Mexican Americans (5.4\%), French Americans (4\%), Polish Americans (3\%), Scottish Americans (1.9\%), Dutch Americans (1.6\%), Norwegian Americans (1.5\%), and Swedish Americans (1.4\%).

Today, the American Jews has enjoyed the privilege of White people. The treatment the society gave them very much different from the past, when anti-semitism still infected the society and they still considered as non-white. Although anti-semitism does not disappear altogether, the quantity of it has decreased. They have hold the control in society, economy, and politic, which means that they also can influence the government. The existence of Jewish lobby such as AIPAC (American Israel Public Affairs Committee) is one of the example of American Jews' progress in American society. The elevated social status of the American Jews has its correlation with their acknowledgement as a white ethnic. Thus, this study aims to examine the changes of social status of the American Jews as they emerged as the white ethnic. Therefore, from this introduction, the problems that are formulated are why the American Jews can be determined as a white ethnic an how the American Jews perceived and see themselves as a white ethnic.

\section{DISCUSSION}

\section{Early American Jews}

Before the term 'white' has become general term referring to white skinned or European descent, it was divided into ethnics or what it called as white ethnic. There are eight white ethnic group, the largest is the WASP, Germans, Scandinavians, Irish, South European Catholics (mostly Italians), and East European Catholics. Although according to the U.S. Census Bureau, Middle Eastern also categorized as white, however Arab Americans often have stronger identification with their country of origin than with a white identity (McDermott and Samson, 2005).

The existence of white ethnic in America can be traced back from the $19^{\text {th }}$ century, when huge number of immigrants are come to America because of American industrial development. The people from Eastern and Southern European came and settled in America to become industrial labor, specifically menial worker. This situation continued until the Congress enacted the Johnson-Reed Act or Immigration Act of 1924, which limited the annual immigrants allowed entry into America through a nation origins quota ${ }^{1}$.

This situation got better in 1970s, when the term 'white ethnic' was a popular issue.

\footnotetext{
1 Taken from https://history.state.gov/milestones/19211936/immigration-act
} 
The ethnic revival mainly inspired by the organization of Civil Rights movement and the minority nationalist movements (Cardon, 2012). As it is stated by Jacobson, the Civil Rights movement had heightened whites' consciousness of their skin privilege, rendering that it is not only visible but also uncomfortable (Jacobson, 2006). Therefore, the ethnicity changed from a badge of shame to a badge of pride. At the time, the Jews felt they can sympathize with the suffering of the African American, perceiving that they have the same fate which strengthens their relationship.

From these changes too, there are several scholars such as Nathan Glazer and Daniel Patrick Moynihan who declare that there is no such a melting pot,

The notion that the intense and unprecedented mixture of ethnic and religious groups in American life was soon to blend into a homogenous end product has outlived its usefulness, and also its credibility... The point about the melting pot... is that it did not happen (Jacobson, 2006).

Though they have the same skin color, the immigrants from Southern and Eastern European at the time were considered lower class, with WASP as the higher class citizen. In addition, most of these immigrants were practicing Roman Catholicism, Eastern Orthodox Christianity, Islam, or Judaism. The difference of culture and lifestyle between them and the WASP is quite contrast. Therefore, the white ethnic retain a strong sense of identity as an ethnic (Berger, 1971).

In her article, Karen Brodkin argues that there are stratification within white identity itself. This notion was popular around the late nineteenth and early decades of the twentieth century, when it is common to think that there are inferior and superior European. The WASP undoubtedly became the superior one, and the other European descent such as Polish, Italian, Spanish were fallen into inferior European category. From this consensus, it can be assumed that Jews were seen as an inferior ethnic or race. This prejudice then peaked in the 1920s and 1930s when anti-Semitism notion continued to harden the position of Jews in America.

\section{The Census}

During the change of social status of the American Jews, there are several events which influence the census questions at the time. The questions regarding race and skin color are changed several times. The most critical change was when President F.D. Roosevelt took office. At the 1940 federal census, the questions no longer distinguished native whites of native parentage from those of immigrant parentage. There's no doubt that this census helps in merging Jewish people into the mainstream of American society. Besides name, age, relationship, and occupation, the 1940 census included questions about internal migration; employment status; participation in the New Deal Civilian Conservation Corps (CCC), Works Progress Administration (WPA), and National Youth Administration (NYA) programs; and years of education. The precedent census still separating the data about the native white parentage with the immigrant parentage. It is also not unintentional that this happen while President Roosevelt was in office.

Franklin Delano Roosevelt, or often called as FDR, was the $32^{\text {nd }}$ President of the United States and held office in March 1933 through April 1945. The 1940 census reflects economic 
tumult of the Great Depression and President Franklin D. Roosevelt's New Deal recovery program of the 1930s. He took over his predecessor Herbert Hoover and dealt with the World War II during his entire term. In the early until the middle of this term, Roosevelt known as having a close ties with American Jews. Roosevelt followed the 1928 presidential candidate's path Al Smith who was surrounded by Jewish advisors. In his term, he used Jewish advisors and appointees, and told the native born audiences that immigrants were "fully American", and arguing during 1936 campaign that "in some cases the newer citizens have discharged their obligations to us better than we have discharged our obligations to them" (Slayton, 2017). His effort in facing the nativism and anti-semitism ultimately benefiting the American Jews at the time. Although ironically, toward the end of his term Roosevelt, as it is written by Zuckerman, deliberately and coldly abandoned Europe's Jews in their hour of need, and resulted in a prolonged blame by the Jews, even until today.

The 2000 federal census also pose the same importance regarding the change about race and ethnicity. In this census, the census questionnaire for the first time did not require respondents to choose between racial and ethnic identities. Census 2000 asked separate questions on race and Hispanic or Latino origin. The Hispanics who reported their race as White, either alone or in combination with one or more other races, are included in the numbers for Whites. In this census, the term "White" refers to people having origins in any of the original peoples of Europe, the Middle East, or North Africa. It includes people who reported "White" or wrote in entries such as Irish, German, Italian, Lebanese, Near Easterner, Arab, or Polish(U.S. Census Bureau, 2001).For instance, the respondent may choose to write Jewish, or White and Jewish. Rather, they could select all that applied, like black and Hispanic or white and Latino, said Shaul Kelner, associate professor of sociology and Jewish studies at Vanderbilt University.

From these censuses, it can be seen that the censuses prior to 1940 census contains a discriminative questions towards immigrant. Particularly in 1850 census, since the huge immigration from Southern and Eastern European resulted in a nativism view and brought the negative stigma towards the immigrants. The fear that they will be dominated by the immigrants, made the White created several associations and leagues in order to voice their concern about the growing number of immigrants. These associations mentioned before purposed to oppose the coming of immigrants to America. The nativism view also caused by the poor living condition of the immigrants which were viewed as tainting the face of the states.

However, the census questions since 1940 census and after have a more lenient view and tend do benefited the immigrants or ethnic minority. The questions regarding race and immigrant parentage were dropped one by one in each census. The 1940 census was held coincided with President Franklin Delano Roosevelt took office. When President Roosevelt took the mantle of presidency, the Great Depression occurred. The economical tumult that happened at the time surely made the American suffer. With his New Deal program, he produced a political realignment, making the Democratic Party the majority (as well as the party that held the White House for seven out of the nine presidential terms from 1933-1969) with its base in liberal ideas, the South, traditional Democrats, factory machines, the newly empowered labor unions 
and ethnic minorities. Following the footsteps of his predecessors Al Smith and Teddy Roosevelt, he surrounded himself with Jewish people. The support given to the immigrants, and particularly the American Jews also won him their support in turn. However, the relationship with the American Jews went sour after American government did not show the willingness to help the Holocaust victims.

However, with the changes from ethnic revival to the change of census question, it has influenced the social status of the American Jews. As the time passed, they were slowly rise within the society and embrace their new position as white ethnic and gain the advantage the status can offer.

\section{Social Identity Theory}

According to Greene (2004), Social identity theory attempts to explain how selfperceived membership in a social group affects social perceptions and attitudes. Social identity is defined as "that part of an individual's self concept which derives from his knowledge of his membership of a group (or groups) together with the value and emotional significance attached to the membership" (Tajfel, 1978). The theory holds that individuals attempt to maximize differences between the in-group (the group to which one psychologically belongs) and the out-group (psychologically relevant opposition group) and thus perceive greater differences between one's in-group and the relevant out-group than actually exist and show favoritism toward in-group members (Tajfel and Turner, 1986). More importantly, these social identifications are not based on any formal group membership, but rather selfperceived membership in a particular group.
- The Accentuation Effect

In the accentuation effect, the individual will accentuate the similarity and differences with other groups, or in this case, with other out-groups. This process also transforms individuals into groups. The sense of belonging toward the group started to be developed in this process. The accentuation effect, though very subjective, still have a base foundation where they share the same conclusion with the fellow in-group. The assessment of the in-group also tend to have more positive assessment than the out-group. Therefore, the result of the accentuation effect is to increase the perceived differences between in-group and out-group. Of course, the beginning of the process will come from the self, which that is when the selfcategorization will occur and lead to social categorization.

\section{- The Social Comparison}

After the accentuation effect took place, the social comparison then will began its course. Different from the accentuation effect, social comparison focuses its view on physical reality which formed through consensus. Because it formed through consensus, this will resulted in a certain perspective which is hard to be challenged. The intergroup comparison can rendering the in-group to become more distinctive than the out-group, thus validating its social identity. This happens when the American Jews compare their physical features with other ethnics, and also other things that can be visualized such as economical status (this can be seen from the house type and the neighborhood, or their way of life includes fashion, food, and etc.). 
- Subjective Belief Structure

The last process is subjective belief structure. This structure explains about social mobility and social change. The social mobility is the boundaries between groups which is permeable. While social mobility often being seen as myth, since it is very hard to move the social status of a group, social change is a rigid boundary and impermeable. In the subjective belief structure, there are four points that can determine the individual's choice of which social comparison type that the are going to apply. The relation between in-group and outgroup at least have to fulfill the following terms:

1. The relative status of groups

2. The stability of the status relationship

3. The legitimacy of the status relations

4. The permeability of intergroup, and the possibility of leaving one group and becoming the member of the out-group (psychologically).

Social category only exists if there are contrasts within society. The social categorization of the American Jews immigrant, or the second generation perhaps started when they were small. As it was stated by Brodkin (2017) who felt there's no boundaries between her friends when they were little, that such awareness only started to grow while she moved to a various ethnic and religious backgrounds neighborhood with Irish, and Italian, Protestant, even Republican people. This process of self and social categorization will dawned on the individual, as they become more conscious of their ethnic and racial background, where the first step of social identity take place: the accentuation effect.
The American Jews, especially the Whites, are physically similar with the Anglo Saxon. Or it can be said that the Jews are more similar with the Whites than the Blacks or the Asian. In the categorization of in-group and outgroup, the American Jews will be easily slipped into the group where the Anglo Saxon are. Although there are sources that argued that American Jews are their own ethnic and cannot be categorized into any of the existing categories, however the similarities cannot be undermined. As it was said by Eric Goldstein, the author of The Price of Whiteness: Jews, Race, and American Identity (2006),

"Jews were a racial conundrum, a group that could not clearly be pinned down according to the prevailing racial categories." Yet they were still distinct, and "in the minds of white Americans, Jews were clearly racial outsiders...demonstrating distinctive social patterns, clustering in urban neighborhoods... and largely marrying within their own group."

The accentuation effect of American Jews can be found in many fields, such as politic, economy, and social field. One of the implementation of accentuation effect can be found in American housing system and real estate market. The segregation between the whites and the non-whites have not ended. From the HOLC (Home Owner' Loan Corporation) housing map, it can be seen that the Whites and Blacks have their own housing area where the concerned color is the majority. In the complex where the Blacks are the majority, the price of the house is cheaper than the house in the white majority area. The existence of non-white, especially Black people in an apartment building with predominantly white people also will decrease the value of the that building. 
According to an article by Jamelle Bouie (2015), the HOLC map divide cities and neighborhood according to various risk categories based on ethnic hierarchy, and mark them differently through colors. For the white neighborhood, the map will be colored with the color green, which also representing an affluent WASP citizen. Meanwhile, the color blue represents the other white ethnics such as Jews, Irish and Italians which is stable and upwardly mobile. The color yellow is the mark for the white working class neighborhood, while red is for the neighborhood that is predominantly Black or Mexican, regardless of the wealth and class.

From the point of view of whiteness, the American Jews might consider the in-group is to belong to the group with another white ethnics and the WASP, since they belong to the same color. As the accentuation effect relies heavily on human instinct in accentuating the characteristics between the group, thus the differences in skin color would be the first thing that is pointed out. If this is the case, then the out-group would be the non-whites such as African American and Asian American. With this setting, it is easier to accentuate the differences with the out-group. Furthermore, the white privilege will be assessed as the positive value of the in-group, because only the whites who can enjoy those privileges.

After the accentuation effect took place, the next step is social comparison. One example is the debate of several readers in Commentary (April 1, 1969) ${ }^{2}$ about The Black Revolution and the involvement of Jews, Blacks and Wasps. This debate shows how

\footnotetext{
${ }^{2}$ The full debate can be found in https://www.commentarymagazine.com/articles/whycant-they-be-like-us-americas-white-ethnic-groups-byandrew-greeley/.
}

from the point of view of the Blacks, Jews often behave like the WASP (in a negative manner) when they are expected to act better than WASP. Whereas the Jews tried to distance themselves from the case being discussed and emphasizing the issue of anti-Semitic. From this elaboration, it can be seen that the Jews would have the similar views about the nonwhites (the African American in this matter), which also lead them to act like the WASP when it is related to the non-whites.

This perspective is already socially constructed, which means that it cannot be changed easily. When the self-categorization and self-comparison operate together, it generates a specific form of behavior which called group behavior. From the example above, the group behavior of the American Jews and the WASP both were similar. The group behavior also lasted for a long time, and it cannot be changed (perhaps only if there is a certain huge event like revolution, but still, the possibilities are shallow).

In connection with the notion of American Jews as White itself, it has divided the American Jews into two different groups, one which claim and admit themselves as white, and also the other one which refuse to be categorized into any known category and choose to accentuate their ethnicity and claim themselves as "Jewish". From these groups, the American Jews were trying to portray themselves through the two types of social comparison which goal is to maximize the positivity of public stigma towards them.

There are two types of social comparison, which is downward social comparison and upward social comparison. Just like how its called, downward social comparison is a social comparison which goal is self-evaluation. 
According to Suls and Wheeler (2000), selfevaluation is satisfied by making comparisons with people who are generally similar but slightly better than oneself. It happened when there are threats to self esteem. Whereas upward social comparison which goal is selfenhancement. Self enhancement is made by comparing oneself with the group that is worse than the in-group. The downward social comparison often happened in the satirical and ironic stories and jokes made by Jewish toward themselves. On the one hand, it seems that these jokes and stories were made to react to the negative stigma about them. On the other hand, it is because of the long tradition that Jewish humor that laughs in the face of authority. In the traditional matter, it is found that several linguists suggests that the vernacular inventiveness of the Yiddish language can be regarded as a satire on the formality of German.

The downward social comparison often happened when American Jews is being compared with the WASP. As the initial settlers in America, the WASP indeed has the upper hand. Not to mention that from the colonial era until today, the WASP still manage to sit on the top of societal pyramid. The satirical jokes and stories mentioned above also made or created when there are contiguity between American Jews and the WASP. The WASP can represents the position of authority. Therefore, when compared with the WASP, the self-evaluation will happen in the form of the jokes and stories with a satire and ironical style.

The upward social comparison is happened when an individual or group need to have a positive value that can strengthen their identity. The comparison between, for example, the American Jews and Irish descendants from the (national) economic point of view will show that the former have a more stability and wealth than the latter. The Irish, although also categorized as white, does not have the other benefits and achievements that is possessed by the Jews. The high number of educated people, the percentage of accumulated wealth, and the strong lobby are possessed by the Jews. The Irish, in the other hands, although they also manage to secure several governmental position and jobs area, cannot emulate the power the Jews has. The social comparison between them will enhances the self assessment of the Jews towards themselves. This kind of comparison will also stimulate a sense of pride and more positive feeling towards the group (if the in-group is American Jews). Therefore, it can strengthen the individual's sense of belonging toward the group.

Both of these social comparison intent on differentiating the in-group from the out-group, by creating the positive values and understanding the negative values to improve the in-group's quality which resulted in a strong sense of identity. The strategy to choose which kind of social comparison is called subjective belief structure.

First of all, the relative status of both American Jews and the WASP is stable and strong. Although WASP is considered higher than the American Jews (in terms of the power possession in American society), in many sides, both of them can be said as equal. The WASP with the longstanding position and power in the society, and the Jews, with their growing power and strong lobby force. However, although have a similar stance, it is hard to move to another group with their own perspectives and group behavior. Because in the eyes of the WASP, the only rightful power 
in the United States is them. This can be seen from the actions made by the White extremist or even the $\mathrm{KKK}(\mathrm{Ku}$ Klux Klan) towards another group outside the WASP. Particularly towards the Jews, the anti-semitism is still existed in the society, although it was not as severe as the past times. Some experts even say that the anti-semitism does not really vanish in the society. The past attack toward the Jews does not decrease but rather that another group has become a new target. The actions made by the incumbent President Donald Trump also can be set as an example for this matter. When the policy regarding illegal immigrant were made and the border wall between the United States and Mexico was built, there are many other groups that worried about their own position in the society, including the American Jews.

The relationship status between American Jews and the WASP is relatively stable. Most of the time, both of the groups get along really well, as long as there are some kind of agreement between them. Because of the ties of the American Jews and the state of Israel, and also the relationship between the United States and Israel, it cannot be denied that American Jews have an important position in the American society. These ties and the mutual benefit acquired from it has keep the relationship between the United States and Israel. And therefore, also the relationship between American Jews and the WASP, as the representation of whiteness and authority in the United States (the governmental position mostly covered by the WASP). Although the voice of American Jews cannot be represented by Israel $^{3}$, the historical relation between them is still strong. Therefore, it is not easy to make

\footnotetext{
${ }^{3}$ The recent activity shows the strife between American Jews and Israel regarding the issue of Palestine.
}

the relationship between American Jews and the WASP to crumble, despite of the enmities such as anti-semitism happened around them.

The legitimacy of the status relations placed in the same skin color the American Jews and the WASP were born with. The rule of whiteness is the base of the relationship between the American Jews and the WASP. Because with all the American Jews' achievement, without being white, it is questioned whether their relationship with the WASP and their position in the society would be just like today.

Because whiteness is the foundation of who the American Jews are and the determiner of their position in the society today. Furthermore, the American Jews as a white ethnic makes their position to be more exclusive and unique. The mixture of 'white' and 'ethnic' has not only enable the American Jews to get the benefit of white privilege, but also the sense of belonging towards their ethnicity.

\section{CONCLUSION}

The American Jews being determined as white ethnic was started when the ethnic revival occurred. The ethnic revival was the trigger that stimulated changes of American Jews' social status. Especially when President Roosevelt took office, where he took several of the American Jews as his close advisor, and also the changes made in the census question had gradually change the status of the American Jews. From the scorned and bullied, these changes made the American Jews rise and have a higher social status than before.

As the white ethnic revival occurred, the Jews realized their position as both white and ethnic. The ethnicity which before acted as a 
badge of shame changed into the badge of pride. When the American Jews have successfully assimilated into the society, they become more attached to their ethnicity and even prefer to be called as Jewish rather than as white. The ethnic revival also did not make the Jews perceived as the second class citizen and separated from the WASP anymore. On the contrary, it enabled the Jews claim their own place in the society. Therefore, with a strong political and financial influence, also a suitable skin color, the American Jews have succeeded in assimilating into WASP society.

This is can be seen from how nonAmerican Jews perceive and regard the American Jews as the same level as WASP. However, even with their acknowledgement as a white ethnic, it didn't altogether change how the American Jews perceive themselves as 'other'. Although they have been enjoying white privilege, they cannot seem to be merging with the WASP community. They have the exclusivity of an ethnic group, but also get the best benefits of being regarded as white.

Therefore, this research employed social identity theory to have a better understanding of the sense of belongingness of American Jews as a white ethnic as well as lead to more complete measures of ethnic belonging. An individual's attachment to an ethnic and racial group as a meaningful psychological and cultural group is a fundamental aspect of belonging.

The issue of whiteness is not merely the issue of racism, though racism is the root of all the discrimination. But the notion of whiteness as the 'highest' race and controller makes it immune to any changes and instead strengthened its position in the society.

\section{REFERENCES}

Berger, Peter L. (1917 July, 1). Why Can't They Be Like Us? America's White Ethnic Groups, by Andrew Greeley. Retrieved from https://www.commentarymagazine.com/a rticles/why-cant-they-be-like-usamericas-white-ethnic-groups-byandrew-greeley/.

Berghe, Peirre L. van den. (1967). Race and Racism. New York.

Berkman, Jacob. (2009 October, 5). At least 139 of the Forbes 400 are Jewish. Retrieved from http://www.jta.org/2009/10/05/funderme ntalist/at-least-139-of-the-forbes-400-arejewish.

Boiue, Jamelle. (2015 May, 13). A Tax on Blackness. Retrieved from http://www.slate.com/news-andpolitics/2018/03/donald-trump-has-littleto-fear-from-the-fec-over-stormydaniels-payment.html.

Brodkin, Karen B. (2017). "How Did Jews Become White Folks?". Race and Ethnicity.

Bureau, United States Census. (2001). "The White Population: 2000 - Census Bureau." Census 200 Data Product.

Bureau, United States Census. (1980 April, 1). 1980 Overview. Retrieved from https://www.census.gov/history/www/thr ough_the_decades/overview/1980.html.

Cardon, Lauren S. (2012). The "White Other" in American Intermarriage Stories, 1945-2008. New York: Palgrave Macmillan.

Goldstein, Eric L. (2005). "Contesting the Categories: Jews and Government Racial 
Classification in the United States." Jewish History, 19(1), 79-107.

Goldstein, Eric L. (2006). The Price of Whiteness. New Jersey: Princeton University Press.

Greene, Steve. "Social Identity Theory and Party Identification." (2004). Social Science Quarterly, 85(1), 136-153.

Hixson, Lindsay, Bradford B. Hepler dan Myoung Ouk Kim. (2011). "The White Population: 2010." Census Report.

Jacobson, Matthew Frye. (2006). Roots Too: White Ethnic Revival in Post - Civil Rights America. Cambridge: First Harvard University Press.

Jacobson, Matthew Frye. (1999). Whiteness of a Different Color: European Immigrants and the Alchemy of Race. Cambridge: Harvard University Press.

Lewins, Frank. (1978). "Race and Ethnic Relations." Labour History, No. 35, Who Are our Enemies? Racism and the Working Class in Australia, 10-19.

McDermott, Monica and Frank L. Samson. (2005). "White Racial and Ethnic Identity in the United States." Annual Review of Sociology, 31, 245-261.

Sarna, Jonathan D. and Jonathan Golden. (2000 October). The American Jewish Experience in the Twentieth Century: Antisemitism and Assimilation. Retrieved from

http://nationalhumanitiescenter.org/tserve /twenty/tkeyinfo/jewishexpb.htm.

Suls, Jerry dan Ladd Wheeler. (2000). Handbook of Social Comparison: Theory and Research. Boston : Springer.

Tajfel, H. (E.). (1978). Differentiation Between Social Groups: Studies in the Social
Psychology of Intergroup Relations. London: Academic Press.

Tajfel, H. dan J.C. Turner. (1979). "An Integrative Theory of Intergroup Conflict." Austin, W.G. dan S. Worchel. The Social Psychology of Intergroup Relations. California: Brooks/Cole, 3347.

Tajfel, H. dan J.C. Turner. (1986). "The Social Identity Theory of Group Behavior". Psychology of Intergroup Relations, 724.

Turner, J.C. (1982). "Towards a Cognitive Redefinition of the Social Group." Cahiers de Psychologie Cognitive/Current Psychology of Cognition, 93-118. 